\title{
医療用化学吸着剂一一尿素をアンモニアとして除去する “ジアルデヒドデンプン”ーウレアーゼ複合体——
}

(1984 年 10 月 22 日受理)

\author{
清水敏美*・山崎嘉彦** 伊佐 功**.田中芳雄
}

尿素除去は, 多量の透析液などを用いることができない装着型または埋込型人工腎蔵の開発のらえで, 最大急務の課題である。そこで著者らは, 生理条件下での有効な尿素除去剤として“ジアルデヒドデン プン” (DAS) そ着目し，今回，新たに，DASーウレアーゼ複合体からなる尿素分解型化学吸着剤を開 発した。調製法としては，DAS 粒子表面に分布するホルミル基の一部をジアゾ誘導体に変換したのち ウレアーゼを固定化する方法 [(i ) 法 $]$ と, DAS k直接, ウレアーゼを固定化する方法 [( ii $)$ 法 $]$ ，の 二法を用いた。その尿素除去原理は，DAS に固定化したウレアーゼによって尿素をアンモニアに分解 し，その生成アンモニアを残存するホルミル基で化学的に吸着除去することからなる。DAS-ウレアー ゼ複合体のウレアーゼ活性は, 酸化度が $80 \%$ 前後の DAS に, pH 5 付近でウレアーゼを固定化した とき，もっとも大きくなった。（i ）法で得た複合体のウレアーゼ活性の至適 $\mathrm{pH}$ は約 7 であり, $\mathrm{pH}$ 安定性は遊離ウレアーゼにくらべて低下した。（ii）法で得た複合体の尿素除去容量は $18.9 \mathrm{mg} / \mathrm{g}$, 除 去率は $94 \%$ (初期濃度 $2.00 \times 10^{3} \mathrm{mg} \cdot \mathrm{dm}^{-3}$, 透析夜中, $37^{\circ} \mathrm{C}, 24$ 時間) であった。この結果は DAS 単独の場合の 1.4 倍であり, 他の尿素除去例の結果よりはるかに優秀であった。

\section{1 腥 言}

吸着剂を医療用途に適用する場合には，その吸着容量，吸着速 度とともに, 生体適合性, 無書性, 安定性などを総合的に評価す る必要がある。たと竞ば, 活性炭は急性腎不全, 急性肝不全, 薬 物中毒などの疾病の原因となる生体内有機物質を効率よく吸着で きる゙。しい，この活性孷を血液浄化剤として用いる場合, 一 般にその外㲄は，血液適合性のよい高分子材料で被包化されてい る2。こうした医療用活性炭の開発にとるない，透析以外飞，限 外汇過, 血墏分離, 吸着などの原理を応用した人工腎臟の研究も すすんでいる。しかしながら，これらの将来型人工腎蔵は，活性 炭が不得意亡する 1）尿素除去，2）電解質平衡の是正，3）除水 の三つの性能を満足しないかぎり, 僈性腎不全治療法として確立 しえない。とくに尿素は尿中に排泄される有機物質の中で量的に 最大(14 35 g/d) のるのであり, その体内蓄樻は, 生体内酵素な ぞの変性障害をひき起こすといわれる゙〉。したがって, 生理条件 下で有效作用する尿素除去郕の一刻むはやい開発が内外を問わ ず望まれている。

著者らはこれまでに，無毒性の二つのホルミル基をもつニニッ トを含む高分子化合物 ${ }^{4)}$ とて, “ジルデヒドデンプン”（以下

識維高分子材料研究所, 305 茨城県筑波郡谷田部町東

** 日本カーリット株式会社, 377 沿川市半田

1）吉田忠昭, “80年代の医用材料”, テクマート (1980) p. 97.

2) 中林宣男, 化学工業, 28, 505(1983).

3) C. Tanford, Adv. Protein Chem., 24, 1(1970).

4) R. H. Wilson, Proc. Soc., Exp. Biol. Med., 102, 735 (1959).
DAS と略記する) ${ }^{5)}$ (困 1）に着目し，その尿素およびアンモニ アどの化学的親和性 ${ }^{6)}$ を利用して医療用尿素除去剂としての有効

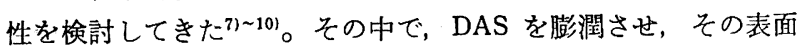
に分布するホルミル基のみを生体適合性のよいアルブミンやゼ チンで不活性化させた, 表面化学処理 DAS を開発しだ。この DAS の, 生理条件下, $1.2 \times 10^{3} \mathrm{mg} \cdot \mathrm{dm}^{-3}$ の尿素溶液に対与る 24 時間後の単位結合容量は約 $8 \mathrm{mg} / \mathrm{g}$ に達し, 今までの尿素除 去例 ${ }^{11}$ の結果よりはるかにすぐれていた。この尿素除去剤の開発 途中, 著者らは, 尿素除去実験系に DAS 重量の $0.5 \%$ の粗ウ レアーゼ (0.17 Units/g) を添加するだけで，見かけ上，残存尿 素濃度が無添加系にくらべて飛躍的に減少する現象を見いだし た。この観点から, 少量のウレフーゼと DAS を複合一体化した 化学吸着剂が，尿素から分解したアンモニアを除去できれば，さ

5) P. J. Borehert, Kunststoffe, 51, 137(1961).

6) J. W. Sloan, B. T. Hofreiter, R. L. Millies, I. A. Wolff, Ind. Eng. Chem., 48, 1165(1956).

7) 清水敏美, 山崎嘉彦, 植田政良, 本田 敳, 田中芳雄, 津 田圭四郎，高分子論文集，39，629(1982).

8) 清水敏美, 下田敬子, 田中芳雄, 佐々木寞治, 津田圭四郎, 秋沢忠男，越川昭三，高分子論文集，39，637(1982).

9）衣笠えり子，秋沢忠男，児島弘臣，田村克彦，関口孝， 中山文義, 高橋 健, 佐藤昌志, 北岡健樹, 出浦照国, 越 川昭三, 清水敏美, 佐々木寛治, 中林宣男, 人工臓器, 11, 40(1982).

10) T.Shimizu, S. Fujishige, J. Biomed. Mat. Res., 17, 597(1983).

11) U. R. Shettigar, Proc. Eur. Soc., Artif. Organs, 7, 102(1980). 


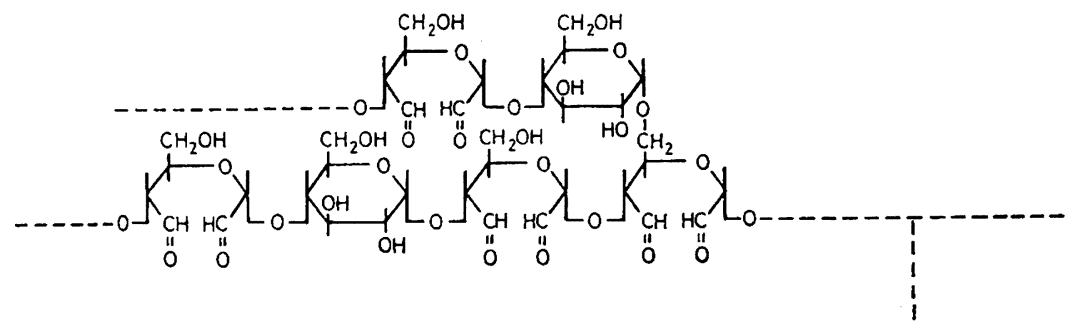

Fig. 1 Structure of "dialdehydestarch" (DAS)

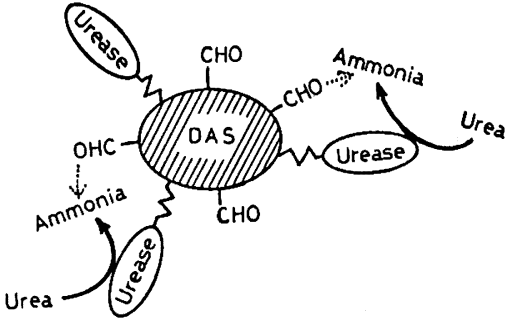

Fig. 2 Schematic representation of the action of DAS-Urease conjugate on the removal of urea

きの表面化学処理 DAS よりさらに効率のよい尿素分解型除去剤 が得られる可能性があると考えた。すなわち，DAS の表面に分 布するホルミル基の一部を利用して，尿素分解䤃素であるウレア 一ゼを固定化し，残存ホルミル基で，尿素分解によって生成した アンモニアを除去するのである（図 2 ）。ちなみに, DAS は尿素 の他にアンモ二ア除去剤としての性能も高く，その除去速度も尿 素に対するよりも速いといわれる12)。また，ウレアーゼの固定化 は，生体内にウレアーゼが遊離するのを防止でき，好ましくない 生体内アンモニア濃度の上昇をおさえることができる。これまで に，人工腎蔵用の尿素処理システムとして，ウレアーゼ固定化担 体を含むカラムで尿素をアンモニアに分解し，それを，直列する アンモニア吸着剤で除去する二段的方法 ${ }^{13)}$ ， ウレフーゼとアンモ ニア吸着剂をマイクロカプセル化した例 ${ }^{14)}$ ，またはアンモニア吸 着剂にウレアーゼを固定化した系 ${ }^{15}$ が知られている。しかし，尿 素およびアンモニアの除去能が高い化学吸着剂にウレアーゼを固 定化した系の報告例はない。

\section{2 試料および実験方法}

\section{1 材 料}

ホルミル基 2 個をもつュニットの含量（以下，酸化度とよぶ） が巽なる 4 種の DAS は, バレイショデンプンの過ヨウ素酸酸化 により得た。酸化度の規制は，デンプンと過ヨウ素酸との仕込み

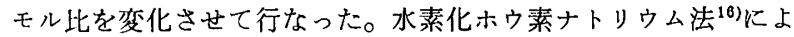

12) L. S. Meriwether, H. M. Kramer, Kidney Int., 10 , S-259(1976).

13) T. M. S. Chang, "Biomedical Applications of Immobilized Enzymes and Proteins", Vols. I and II, Plenum Publishing Corp., New York (1977).

14) T. M. S. Chang, Trans. Am. Soc. Artif. Intern. Organs, 12, 13(1966).

15) C. Kjellstrand, H. Borges, C. Pru, D. Gardner, D. Fink, ibid., 27, 24(1981).
り定量した酸化度は，それぞれ 29.9\%，45.2\%，69.5\%，80.8\% であった。ウレアーゼ（U と略記する）(シグマ社製）はタイプ

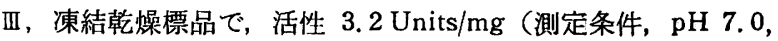
$30^{\circ} \mathrm{C}$ ) と称するものを使用した。

\subsection{DAS へのウレアーゼ固定化}

DAS へのウレアーゼ固定化法として，（i ） 4, $4^{\prime}$-ジアミノジフ ェニルメタン（以下 DADPM と略記する）を用いた Goldstein らのジフゾ法 ${ }^{17)}$ の改良法, (ii) Schiff 塩基構造形成法 ${ }^{18)}$ の二法 を試み，DAS-ウレアーゼ複合体としてそれぞれ，DAS-DADPMU と DAS-U を得た。（i）法，（ii）法の調製スキームを因 3 に示す。二法に共通する調製上の特徵は，DAS と DADPM, または DAS とウレアーゼの反応後形成される Schiff 塩基の還 元処理を行なわないことで，ホルミル基を活性状態のまま残存さ せていることである。というのは，ホルミル基は生成フンモニア の結合官能基であるからである。また，DAS への DADPM 導 入量, DAS-DADPM および DAS へのウレアーゼ導入量は元素 分析の N含量から求めた。

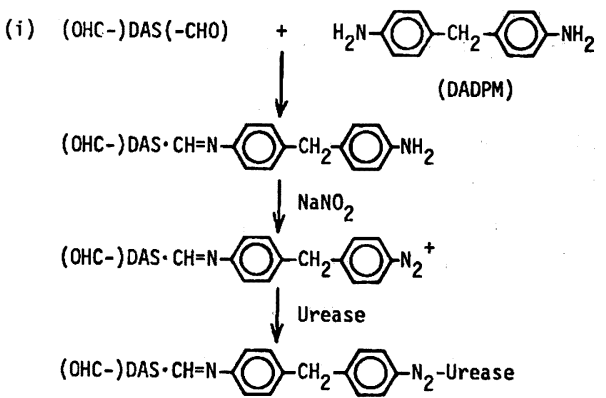

(DAS-DADPM-U)

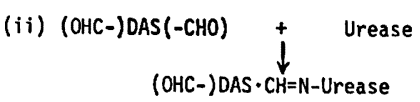

(DAS-U)

Fig. 3 Scheme of preparation of DAS-Urease conjugate

(i): The coupling of diazotized DAS derivatives with urease

(ii): The condensation of DAS with urease

16）渡野辺哲郎, 涉谷盛興, 分析化学, 15, 176(1966).

17) L. Goldstein, M. Pecht, S. Blumberg, D. Atlans, Y. Levin, Biochemistry, 9, 2322(1970).

18) F. B. Weakley, C. L. Mehltretter, Biotech. Bioeng., 15, $1189(1973)$. 
2.2.1 DAS-DADPM-U の調製：2.1で調製した，酸化度が 異なる 4 種の DAS を各 $1 \mathrm{~g}$ 用いて, Goldstein らの方法 ${ }^{17} に$ より DADPM（東京化成製特級試薬） $3 \mathrm{~g}$ を反応させ，DASDADPM 1.5 1.6 g を得た。このときの DADPM の導入率は 35 46\% であった。この 4 種の DAS-DADPM $100 \mathrm{mg}$ をそれ ぞれ酢酸と亜硝酸ナトリウムで処理し, 生成したジアジニウム塩 を蒸留水, つついて反応液と同じ $\mathrm{pH}$ の緩衝液で数回洗浄した。 得られた沈殿物を各種の $\mathrm{pH}$ の緩衝夜 $4 \mathrm{ml}$ に䜿濁し, ウレアー ゼ $10 \mathrm{mg}$ を含む水溶液 $3 \mathrm{ml}$ を加え， $4^{\circ} \mathrm{C}$ で 24 時間かきまぜ た。沈殿物をガラス汇過器で沪過し, $1 \mathrm{~mol} \cdot \mathrm{dm}^{-3}$ 塩化ナトリウ 么水溶液 $100 \mathrm{~m} l$, 蒸留水 $100 \mathrm{~m} l$ で洗浄し, 最終的に凍結乾燥に よって, 褐色粉末の DAS-DADPM-U 複合体を得た。このと き, 各複合体の DAS-DADPM からの収率は 89 94\% であっ た。

2.2.2 DAS-U の調製：ウレアーゼ $100 \mathrm{mg}$ :を各種の $\mathrm{pH}$ の 緩衝液 $2 \mathrm{ml}$ に溶解し，これにかきまぜながら，酸化度 $81 \%$ の DAS $200 \mathrm{mg}$ を加え， $4^{\circ} \mathrm{C}$ で 24 時間反応させた沈殷物をガラス 沪過器で沪過し, $1 \mathrm{~mol} \cdot \mathrm{dm}^{-3}$ 塩化ナトリウム水溶液 $100 \mathrm{ml}$, 蒸 留水 $100 \mathrm{~m} l$ で洗浄し, 最終的に凍結乾燥によって白色粉末の DAS-U 複合体 $199 \mathrm{mg}$ (収率 $99 \%$ ) を得た。

\section{3 ウレアーゼ活性の $\mathrm{pH}$ 依存性と $\mathrm{pH}$ 安定性}

DAS-DADPM-U 複合体のウレアーゼ活性を測定して，活性 の $\mathrm{pH}$ 依存性と $\mathrm{pH}$ 安定性を検討した。ウレアーゼ活性の測定 は，尿素を基質に用いて複合体を作用させ，その分解生成物のア ンモニアを Kaplan の方法 ${ }^{19}$ にしたがって行なった。 $\mathrm{pH}$ 依存性 と $\mathrm{pH}$ 安定性の湘定における反応操作を表 1 に示す。遊離ウレア 一ゼについては，pH 依存性測定の場合， $12.7 \mathrm{mg}$ を緩衝腋 14 $\mathrm{m} l$ に, $\mathrm{pH}$ 安定性測定の場合, $18.2 \mathrm{mg}$ を緩衝液 $2 \mathrm{~m} l$ にそれぞ れ溶解し，複合体を用いたときと同様な操作によってウレアーゼ 活性を求めた。図 4〜9には，DAS-ウレフーゼ複合体および遊 離ウレアーゼのそれぞれについて，全測定の最大值を 100 とし て，その相対活性值（\%) を示してある。

\section{4 尿素除去能の測定}

DAS または DASーウレアーゼ複合体からなる化学吸着剤 100 $\mathrm{mg}$ を, 透析液 (武田薬品工業(株)製の TM-SOLITA の 30 倍 希釈液）で調製した，濃度 $1.00 \times 10^{3} \mathrm{mg} \cdot \mathrm{dm}^{-3}, 2.00 \times 10^{3} \mathrm{mg}$ ・ $\mathrm{dm}^{-3}, 3.00 \times 10^{3} \mathrm{mg} \cdot \mathrm{dm}^{-3}$ の尿素溶液 $1 \mathrm{ml}$ 中に加兄, $37^{\circ} \mathrm{C}$ で 24 時間かきまぜて，尿素除去実験を行なった。そのあと，化学 吸着剂を遠心分離し，それを沪過して沪液 $0.1 \mathrm{ml}$ を蒸留水で 80 倍希釈した。しかし，この希釈夜中の残存尿素濃度を，ジアセチ ルモノオキシム法を用いて直接, 比色定量する方法は再現性が 悪く，この系に対して不適であると判断した。そこで, 系中のフ ソモニアを定量し, 尿素濃度に換算した。すなわち, さきの希釈 液 $0.8 \mathrm{~m} l$ Kウレアーゼ溶液 $(2 \mathrm{Units} / \mathrm{ml}) 0.2 \mathrm{~m} l$ を加え, $37^{\circ} \mathrm{C}$ で 15 分間反応させて残存尿素を特異的に分解した。そして系中 に存在する全アンモニアを Kaplan の方法 ${ }^{19)}$ により比色定量し た。こうして, ウレアーゼ添加前と添加後のアンモニア窒素量の 差から残存尿素濃度（たたし, 複合体に固定化されたウレアーゼ によって，系中の尿素が $100 \%$ ，アンモニアに分解された場合， 実質的には，残存アンモニア濃度を意味する）を算出した。尿素 除去容量は初期尿素濃度と 24 時間後の残存尿素濃度との差から

19) A. Kaplan, Meth. Biochem. Anal., 17, 311(1969).
Table 1 Procedure for measurement of urease activity $\mathrm{pH}$ dependence $\mathrm{pH}$ stability

A suspention of DAS-DADPM-U ( $15 \mathrm{mg})$ in a various buffer solution $^{a)}(1 \mathrm{ml})$
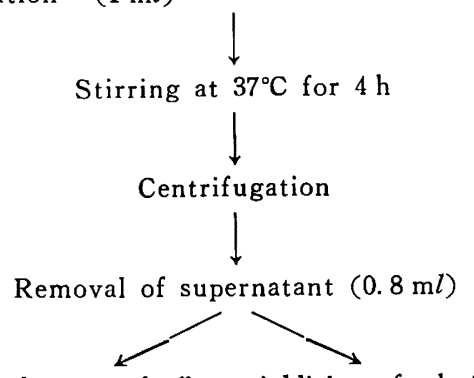

Addition of the same buffer solution containing urea as

Addition of a buffer solution $\left(\mathrm{pH} \mathrm{6.5^{b) }}, 0.8 \mathrm{ml}\right)$ that used at the beginning

$\left(0.21 \mathrm{mmol} \cdot \mathrm{dm}^{-3}, 0.8 \mathrm{ml}\right)$

Stirring at $37^{\circ} \mathrm{C}$ for $15 \mathrm{~min}$ Stirring at $37^{\circ} \mathrm{C}$ for $30 \mathrm{~min}$

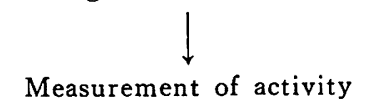

Centrifugation

Measurement of activity

Removal of supernatant $(0.8 \mathrm{ml})$

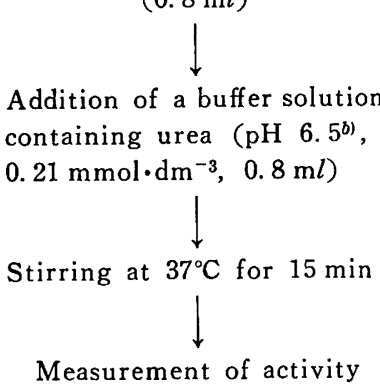

a) $\mathrm{pH} 2 \sim 4:$ Prepared from $0.2 \mathrm{~mol} \cdot \mathrm{dm}^{-3}$ potassium dihydrogenphosphate and $0.2 \mathrm{~mol} \cdot \mathrm{dm}^{-3}$ potassium chloride.

pH 5 13: Prepared from $0.2 \mathrm{~mol} \cdot \mathrm{dm}^{-3}$ potassium dihydrogenphosphate and $0.2 \mathrm{~mol} \cdot \mathrm{dm}^{-3}$ potassium hydroxide.

b) Prepared from potassium dihydrogenphosphate and disodium hydrogenphosphate and added $1 \%$ of EDTA disodium salt.

算出した。

\section{3 実験結果と考察}

\section{1 ウレアーゼ活性におよぼす複合体の調製条件の影響}

3.1.1 pH の影響：ウレアーゼ活性におよぼすDASーウレフ 一ゼ複合体の調製条件の影響を調べるために，まずウレフーゼ固 定化時の $\mathrm{pH}$ の影響を検討した。その結果を図 4 に示す。DASU, DAS-DADPM-U ともに, pH 5 付近で, それぞれウレアー ゼ活性が極大值を示している。また，DAS-DADPM を担体とす る（i）法では，DAS を担体とする（ii）法にくらべて広籁团 の $\mathrm{pH}$ 領域でウレアーゼ固定化を行なっても, 複合体のウレアー ゼ活性が保持されているのがわかる。一般のウレアーゼ固定化反 応における最適 $\mathrm{pH}$ は，ウレフーゼの失活をできるだけ防止する ために $\mathrm{pH}$ 6〜9 の間で行なわれており ${ }^{20)}$ ，今回の最適の $\mathrm{pH}$ 処 


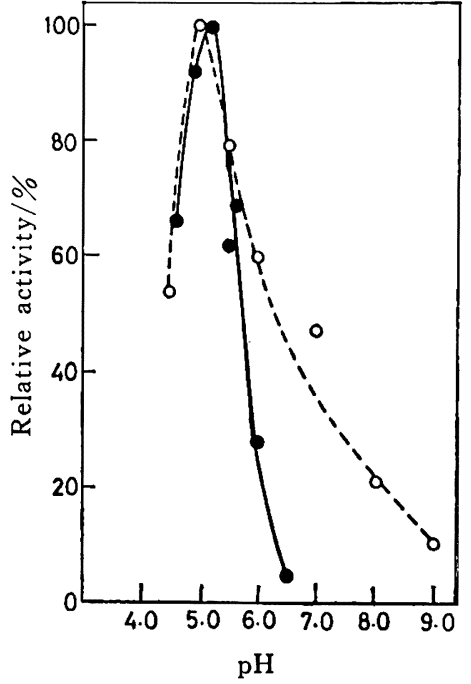

Fig. 4 Effect of $\mathrm{pH}$ of urease solution on the activity of DAS-Urease conjugate

-O : DAS-U, -O- : DAS-DADPM-U

理条件は若干酸性側に移行しているのが特徵といえる。DAS-U の場合，担体 DAS が中性から弱アルカリ性条件で膨潤して活性 化し21)，それがウレアーゼ活性を阻害していると推察できる。す なわち、ウレアーゼの活性中心に存在する遊離メルカプト基が DAS の活性ホルミル基と結合し，活性が低下した可能性が高い。 この結果は,ケラチンへのウレアーゼ固定化において，橋かけ剂

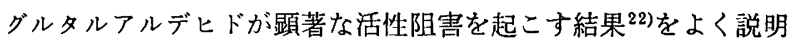
できる。これに対し，DAS-DADPM-U の場合，DADPM が DAS の分子間または分子内に橋かけを形成し，これによって，

同じ $\mathrm{pH}$ では，DAS 単独にくらべ膨潤が抑制されると考壳られ る。そのため, 弱アルカリ性条件下でウレアーゼを固定化しても， さきの DASのような活性ホルミル基による阻害が少ないため,

ウレアーゼ活性が保持されていると推測できる。

表 2 は異なった $\mathrm{pH}$ 条件で調製したときの，DAS-U，DASDADPM-U，それぞれのウレアーゼ含量とウレアーゼ活性を示 している。このときの活性値は, DAS-ウレフーゼ複合体を尿素 に作用させて系の $\mathrm{pH}$ が 6.7 から 7.7 に達するまでの時間から 算出した Sumner 単位 ${ }^{23)} て ゙$ 表示してある。両者の複合体のウレア

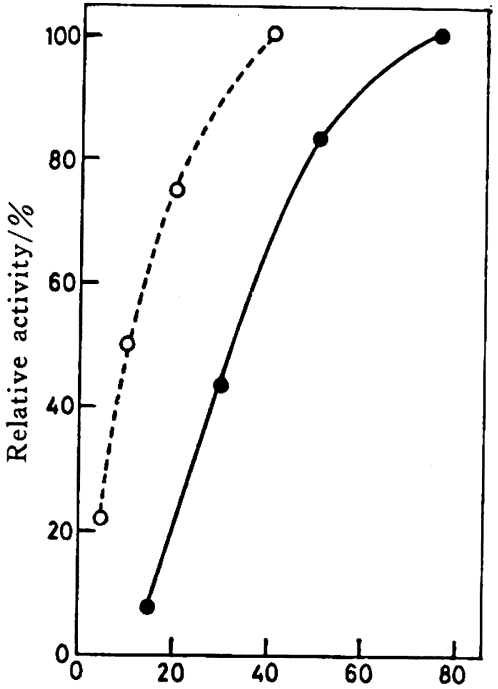

Weight of urease/(mg/100 mg-DAS)

Fig. 5 Effect of weight of urease on the activity of DAS-Urease conjugate

- - : DAS-U, -O- : DAS-DADPM-U

一ゼ含量に大きな相違は認められない。これに対し, ウレアーゼ 活性に大きな差が認められるのは，さきに述べた橋かけによる DAS 分子の高分子構造の安定化とそれによる活性阻書の抑制効 果を反映しているといえる。

3.1 .2 ウレアーセ使用量の影響：つぎ， ウレアーゼ使用量 の活性におよぼす影響を検討した。ウレアーゼ固定化時の $\mathrm{pH}$ 条 件としては，（i）法では pH 5.0，（ii）法では pH 5.2 を用い た。相対活性值を各担体 $100 \mathrm{mg}$ に対するウレアーゼ使用量に対 してプロットしたのが図 5 である。DAS-DADPM とDAS のい ずれを担体とする場合も，本ウレフーゼ使用量範囲では，使用量 が增加するにつれウレフーゼ活性が増大している。本研究の最終 目的は DAS-ウレアーゼ複合体のウレアーゼ活性の大小ではな く，尿素分解によって生成するアンモニアの結合能の大小であ る。そのため, ウレアーゼ使用量を制限した。しかし, 図 5 は, さらに大きいウレアーゼ使用量で，複合体のウレアーゼ活性が向 上することを示唆している。また，表 2 の結果も考虑すると， DAS-DADPM を担体とする場合, DAS を用いる場合とくらべ

Table 2 Effect of $\mathrm{pH}$ of urease solution on the content of urease and the activity of DAS-Urease conjugate ${ }^{a)}$

\begin{tabular}{|c|c|c|c|c|c|c|}
\hline \multirow[b]{2}{*}{ Weight of urease $^{b)}(\mathrm{mg})$} & \multicolumn{3}{|c|}{ DAS-U } & \multicolumn{3}{|c|}{ DAS-DADPM-U } \\
\hline & 50 & 50 & 50 & 10 & 10 & 10 \\
\hline $\mathrm{pH}$ & 5.8 & 6.0 & 6.5 & 5.0 & 6.0 & 8. 0 \\
\hline Content of urease $(\%)$ & 6.0 & 6.1 & 9.1 & 11.0 & 7.6 & 8.3 \\
\hline Activity (Sumner Units/g) & 9.5 & 3.9 & 0.7 & 48.3 & 28. 0 & 10.2 \\
\hline
\end{tabular}

a) Prepared from DAS having $81 \%$ of diformyl unit content.

b) To $100 \mathrm{mg}$ of DAS.

20）たとえば，豊田春和，松永あや子，長南康正，皮革化学， 23, 139(1977)

21) J. F. Haskins, M. T. Hogesd, J. Org. Chem., 15, 1264(1950).
22) 吉川正義, 杉浦正昭, 豊田春和, 皮革化学, 23, 8(1977).

23）赤堀四郎編, “酵素研究法 Vol. 2”, 朝倉書店 (1956) p. 230. 


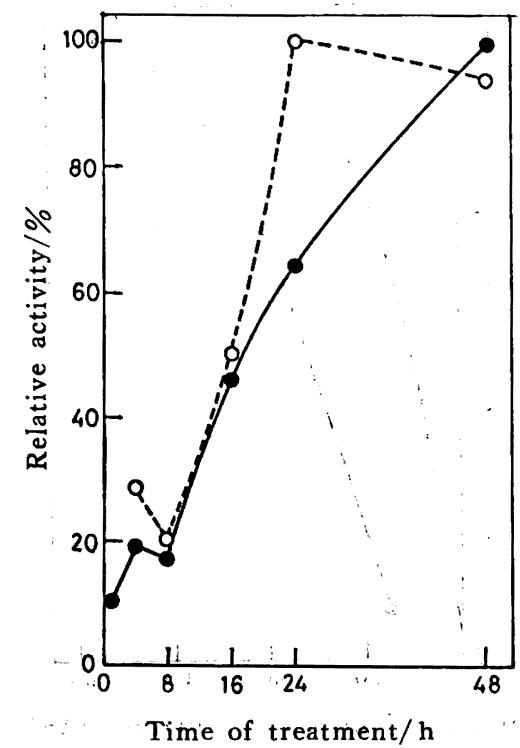

Fig. 6 Effect of time of treatment with urease solution on the activity of DAS-Urease conjugate

- DAS-U, -O- : DÁS-DADPM-U

てかなり低いウレアーゼ使用量で，同等なウレアーゼ活性をもつ ことがわかる。

3.1.3 固定化時間の影響 : 第三に, 固定化時間のウレフーゼ 活性におよぼす影響を図6に示す。DAS-DADPM-U の調製で は24 時間で活性がほぼ一定値になっている。DAS-U の調製で は時間とともにウレフーゼ活性が增大している。この結果は，シ ア゙゙法 ( ( i ) 法) による固定化法の方が Schiff 塩基構造形成法 ((ii) 法) より短時間でウレアーゼとの反応が完了することを示 している。

3.1.4 酸化度の影響：最後に，ウレアーゼ活性におよぼす原 料 DAS の酸化度の影響を検討した。その結果を図 7 に示す。 DAS または DAS-DADPM を担体とするウレアーゼの固定化に おいて， ウレフーゼ活性の酸化度依存性は両者ほぼ同様な傾向を 示し，いずれも酸化度が50～60\% 以上になると急激にウレフー セ活性が増大する。表 3 は，酸化度が異なる DAS を原料に使用 したときの, 担体 DAS-DADPM 中の DADPM 含量, および 最終複合体のウレアーゼ含量とウレアーゼ活性 (Sumner 単位 ${ }^{23)}$ で表示)を示している。興味あることに，酸化度すなわちホルミル 基 2 個をもつユニットの含有量が増加しているにもかかわらず, DAS-DADPM 中の DADPM 含量は若干增加が認められるだけ である。また，DAS-DADPM-U中のウレフーゼ含量はほぼ一 定か, $80.8 \%$ 酸化度では逆に低下している。この結果は，DAS 粒子表面に分布する活性ホルミル基量は，この酸化度範囲ではほ ぼ一定であることを示唆する。デシプンの酸化反応が粒子表面す なわち, Meyer のいらミセル24) 外部から進行していくことを考 えれば,このことをよく説明できる。しかも，DAS と DADPM との反応はメタノール中で行なっているため, DAS 粒子は膨潤 しないで密な構造价とっている。そこで，DADPM は DAS 粒

24) R. W. Kerr, "Chemistry and Industry of Starch", 2 nd ed., Academic Press Inc. (1950) p. 7.

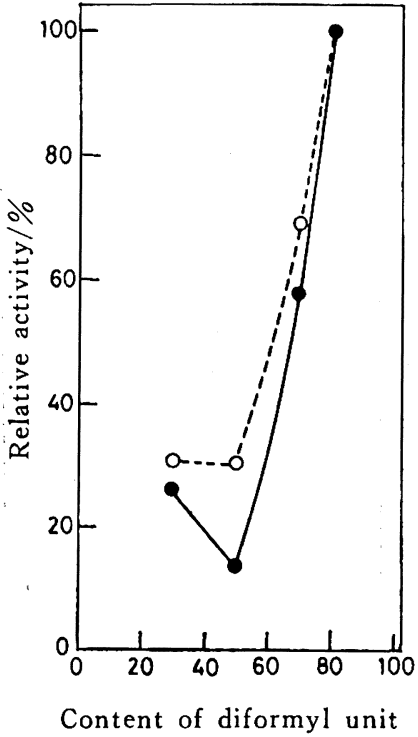

Fig. 7 Effect of diformyl unit content of DAS on the activity of DAS-Urease conjugate

- - : DAS-U, -O- : DAS-DADPM-U

Table 3 Effect of diformyl unit content of DAS on the content of urease and the activity of DASUrease conjugate

DAS-DADPM-U

Content of diformyl unit (\%)

Content of DADPM in DAS-

DADPM $(\%)$

Content of urease $(\%)$

Activity (Sumner Units/g)

$\begin{array}{llll}29.9 & 49.2 & 69.5 & 80.8\end{array}$

$\begin{array}{llll}35.2 & 38.2 & 39.7 & 45.8\end{array}$

$13.2 \quad 13.0 \quad 15.5 \quad 11.0$ $\begin{array}{llll}14.8 & 14.7 & 33.4 & 48.3\end{array}$

子表面のホルミル基とだけ反応したため，DADPM の含有量は 酸化度に依存せずほぼ一定になったと考えられる。また，その DADPM のジアゾニウム塩誘導体と結合するウレアーゼは，こ の理由から同様に，導入量が酸化度の影響をらけなかったと推測 できる。しかしながら，ウレアーゼ活性はウレフーゼ含量に依存 せず，酸化度が高いDAS を使用したときほど，大きくなってい る。これは酸化度が低いDAS を使用したときに，なんらかのウ レアーゼ活性の阻害が起こっていることを示唆している。

\section{$3.2 \mathrm{pH}$ 依存性}

DAS-DADPM-U のウレアーゼ活性の pH 依存性を図 8 に示 す。ウレアーゼ活性は複合体化することで，遊離ウレアーゼにく らべて, 至適 $\mathrm{pH}$ が 2 単位ほど酸性側へ移行して約 $\mathrm{pH} 7$ とな り, 至適 $\mathrm{pH}$ 節囲は 6〜8 とやや狭くなった。これは DAS 分 子の活性阻害が中性から弱アルカリ性条件になるにつれ顕著にな るためと考えられる。しかし，尿素除去は $\mathrm{pH} 7.3 \sim 7.4$ の生理 条件下で行ならことを考虑すると，DAS-DADPM-U の至適 $\mathrm{pH}$ は好都合な条件といえる。

\section{$3.3 \mathrm{pH}$ 安定性}

DAS-DADPM-U のウレアーゼ活性の pH 安定性を図 9 に示 す。複合体の場合, 遊離ウレアーゼにくらべてとくにアルカリ性 側での安定性が悪くなった。これはさきに述べたように，DAS 


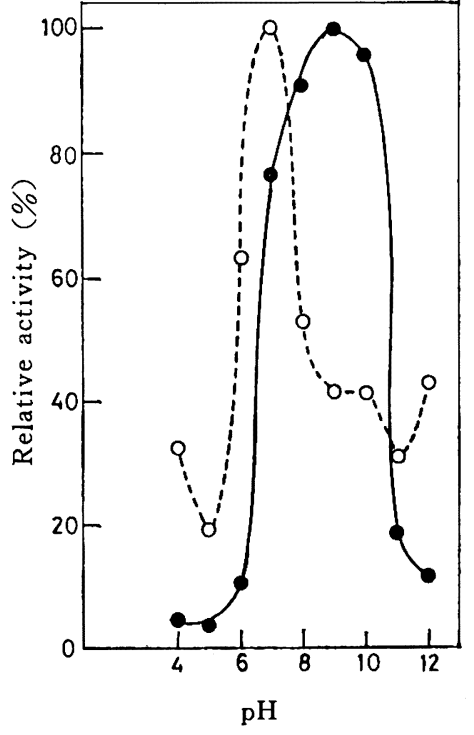

Fig. 8 pH-activity curves for native urease and DASUrease conjugate

- : Native urease, -O- : DAS-DADPM-U

粒子がアルカリ性条件において膨潤し，活性化したホルミル基 ${ }^{22)}$ がウレアーゼの活性中心にある遊離メルカプト基と結合して活性 を低下させた結果を反映していると思われる。

\section{4 尿素除去能}

酸化度が $80.8 \%$ の DAS，およびそれを用いて調製した DAS$\mathrm{U}$ 複合体と DAS-DADPM-U 複合体の 3 種類の化学吸着剂を用 いて, 初期濃度が異なる 3 種の尿素溶液に対する尿素除去実験を 行なった。それぞれの化学吸着剤の 24 時間後の尿素除去率と単 位除去容量を表 4 に示す。参考のため, それぞれの化学吸着剤の ウレアーゼ活性も合わせて示す。いずれの化学吸着剂も初期尿素 濃度が増加するにつれ, 注比例して単位除去容量は増大してい る。また，尿素除去率は，初期尿素濃度に関係なくほぼ定とな っている。つぎ，DAS-Uに注目すると，尿素除去容量はDAS 単独にくらべ, 約 1.4 倍に増加している。この除去容量は, いま までに報告された尿素除去例 ${ }^{11}$ よりはるかに大きい值を示してい る。また，尿素除去率は 95\% に達し，著者らがさきに開発した 表面化学処理 DAS ${ }^{718)}$ を用いたときのほぼ同条件下での除去率を 上回る。これに対し, DAS-DADPM-U の場合, 単位除去容量 は DAS 単独の場合の 60〜70\% に低下している。

DAS-U のウレアーゼ活性が 2.3 Units/g ということは, この

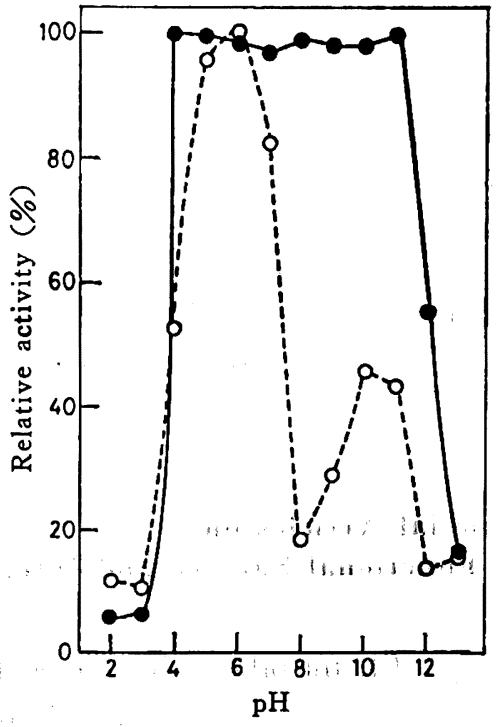

Fig. 9 pH-stability curves for native urease and DASUrease conjugate

- - : Native urease, -O- : DAS-DADPM-U

化学吸着剤 $1 \mathrm{~g}$ が 5 分間で分解できる尿素は約 $4.9 \mathrm{mg}$ である ことを意味する。したがって，DAS-U 複合体と尿素含有試験液 との浴比が 0.1 であり, 除去時間が 24 時間の場合, DAS-Uは 尿素濃度 $3.00 \times 10^{3} \mathrm{mg} \cdot \mathrm{dm}^{-3}$ の溶液中に含まれる尿素をすべて アンモニアに分解し，そのアンモニアを結合除去していると考兄 られる。同様に, DAS-DADPM-U はウレアーゼ活性が DAS-U より非常に高いことから，尿素からアンモニアへの/分解効率は 100\%と考えられる。DAS-DADPM-Uを使用したときの残存 尿素濃度を定量したさい(実験 2.4 参照), ウレアーゼ溶液の添 加前と添加後とで定量したアンもニア濃度には差が見られなかっ た。この結果はさきに述へた推定が正しいことを裏つける。しか し, DAS-DADPM-U の場合，ホルミル基がます DADPM と の反応に消費されたため，アンモニア除去のための活性ホルミル 基数が相対的に減少し，尿素除去能（この場合、アンモニア除去 能）が低くなったと考えられる。こうして，ジアン゙化法によって 尿素除去用 DAS-ウレアーゼ複合体を調製する場合，ウレアーゼ 活性を高め, しかもより多くの活性ホルミル基を残存させる工夫 が必要であることがわかる。現在，その条件を検討中である。

\section{4 結 論}

“ジアルデヒドデンプン”（DAS）を原料にして，活性ホルミル

Table 4 Capacities of urea uptake by various "dialdehydestarch" derivatives ${ }^{a)}$ at $37^{\circ} \mathrm{C}, 24 \mathrm{~h}$

\begin{tabular}{|c|c|c|c|c|c|}
\hline \multirow{2}{*}{ Chemisorbent } & \multirow{2}{*}{$\begin{array}{c}\text { Activity } \\
\text { (Sumner units/g) }\end{array}$} & \multicolumn{4}{|c|}{ Initial concentration of urea $\times 10^{-3}\left(\mathrm{mg} \cdot \mathrm{dm}^{-3}\right)$} \\
\hline & & & 1.00 & 2.00 & 3. 00 \\
\hline \multirow{2}{*}{ DAS } & \multirow{2}{*}{0} & Uptake rate $(\%)$ & 65.9 & 68.2 & 70.1 \\
\hline & & Uptake capacities $(\mathrm{mg} / \mathrm{g})$ & 6.6 & 13. 7 & 21.0 \\
\hline \multirow{2}{*}{ DAS-DADPM-U } & \multirow{2}{*}{31.6} & Uptake rate $(\%)$ & 50.8 & 49.4 & 43. 2 \\
\hline & & Uuptake capacities $(\mathrm{mg} / \mathrm{g})$ & 5.1 & 9.9 & 12.9 \\
\hline \multirow{2}{*}{ DAS-U } & \multirow{2}{*}{2.3} & Uptake rate $(\%)$ & 95.0 & 94.3 & 94.3 \\
\hline & & Uuptake capacities $(\mathrm{mg} / \mathrm{g})$ & 9.4 & 18. 9 & 28.3 \\
\hline
\end{tabular}

a) PreparedIfrom DAS having $81 \%$ of diformyl unit content. 
基を含有する DAS-ウレアーゼ複合体を調製した。そして，酵素 化学的性質および医療用尿素分解型化学吸着剂としての性能を評 価し，つぎの結論を得た。

1）DAS-ウレアーゼ複合体のウレアービ活性は，酸化度が $80 \%$ 前後の DAS を用いて, $\mathrm{pH} 5$ 付近でウレアーゼを $24 \sim 48$ 時間固定化したものが大きくなった。

2）ジアゾ化法により得た DASーウレアーゼ複合体のウレアー ゼ活性の至適 $\mathrm{pH}$ は，遊離ウレアーゼにくらべて酸性側へ移行 し，約 7 となった。また，至適 $\mathrm{pH}$ 範囲は 6〜8 と狭くなった。
3）ジアジ化法により得た DASーウレアーゼ複合体のウレアー ゼ活性の $\mathrm{pH}$ 安定性は, 遊離ウレアービにくらべてアルカリ性侧 で低下した。

4）Schiff 塩基㔍造形成法により得たDASーウレアーゼ複合休 の単位㲾素除去容量は $18.9 \mathrm{mg} / \mathrm{g}$ ，尿素除去率は $94 \%$ （初期濃 度 $2.00 \times 10^{3} \mathrm{mg} \cdot \mathrm{dm}^{-3}$ ，透析液中， $37^{\circ} \mathrm{C} ， 24$ 時間)であった。 この結果は DAS 単独の場合の 1.4 倍であり、これまでに報告 された尿素除去例の結果をはるかに上回った。

\title{
Special Articles on \\ Functional Surface and Interface
}

\author{
Chemisorbent for Medical Use___ "Dialdehydestarch"-Urease Conjugate \\ for Removal of Urea as Ammonia- \\ Toshimi Shimizu*, Yoshihiko Yamazaki**, Isao Isa** and Yoshio Tanaka \\ Research Institute for Polymers and Textiles; Yatabe-Higashi, \\ Tsukuba-gun, Ibaraki 305 Japan \\ ** The Japan Carlit Co., Ltd.: Handa, Shibukawa-shi 377 Japan
}

The removal of urea from dialysate or hemofiltrate is one of major problems for developing implantable or wearable artificial kidney systems. "Dialdehydestarch"(DAS)-Urease conjugates (DAS-DADPM-U and DAS-U) have been prepared to provide an effective chemisorbent for urea under physiological conditions. Urease immobilized on the surface of DAS particle hydrolyzes urea into ammonia $\left(\mathrm{NH}_{3}+\mathrm{NH}_{4}{ }^{+}\right)$. This ammonia then reacts with active formyl groups of DAS (Fig. 2). DAS-DADPM-U was prepared by the coupling of diazotized DAS derivative with urease (Fig. 3). DAS-U was prepared by the condensation of DAS with urease to form Schiff's base structure (Fig. 3). When DAS having $80 \%$ of diformyl unit content was treated with a mild acidic solution of urease (ca. $\mathrm{pH} 5$ ), the most active conjugate was obtained (Fig. 4). The pH optimum of DAS-DADPM-U was at 7 (Fig. 8). Its $\mathrm{pH}$ stability decreased in high $\mathrm{pH}$ range, when compared with that of native urease (Fig. 9). Binding studies have shown that the capacity of urea uptake and the rate of urea uptake by DAS-U can reach $19.8 \mathrm{mg} / \mathrm{g}$ and $94 \%$, respectively (initial concentration of urea, $2.00 \times$ $10^{3} \mathrm{mg} \cdot \mathrm{dm}^{-3}$; in dialysate ; at $37^{\circ} \mathrm{C}$; after $24 \mathrm{~h}$ ) (Table 3 ). This capacity is 1.4 times greater than that of original DAS and far greater than that reported so far. 